\title{
半導体ナノスピントロニクス・デバイス
}

周逸凱*1. 朝日一*1

\section{Semiconductor Nanospintronics Devices}

\author{
Yi Kai ZHOU and Hajime ASAHI
}

The Institute of Scientific and Industrial Research, Osaka University 8-1, Mihogaoka, Ibaraki, Osaka 567-0047, JAPAN

(Received March 22, 2006, Accepted August 5, 2006)

\begin{abstract}
This paper introduces the features and basic principles of the representative spintronics devices-MRAM, spin FET and circular light LED, especially which are fabricated by ferromagnetic semiconductors. It implies that the development of room temperature ferromagnetic semiconductor is very important towards the realization of semiconductor spintronics devices. The properties of transition metal $(\mathrm{Cr})$ and rare-earth element $(\mathrm{Gd})$ doped $\mathrm{GaN}$, which show ferromagnetism at room temperature, are reviewed. The observation of TMR effect in $\mathrm{GaCrN} / \mathrm{AlN} / \mathrm{GaCrN}$ trilayer shows the possibility of GaN-based room temperature ferromagnetic semiconductor for semiconductor spintronics devices.
\end{abstract}

\section{1.はじめに}

エレクトロニクスの更なる発展によって，高度な情報通信 が可能な社会，言わば，ユビキタス社会が到来している。そ れを確実に実現していくためには，現有のエレクトロニクス 機器を根底から支えている集積回路やデバイスを極めて高性 能化させる必要がある. アプローチは, 様々な分野で行われ ている. 特に, 次世代デバイス用の新材料, ナノ材料やナノ デバイスなど研究開発競争が激しく展開している.

新材料の研究領域では, 現代のエレクトロニクスを支える 二つ重要な材料である半導体と磁性体の融合によって生まれ た強磁性半導体材料は大変注目を集めている，今まで，電子 の 2 つ自由度-電荷とスピンは別々に利用されて来た.こ の 2 つ自由度を 1 つのシステム゙利用することによっ て，新たな，より高度なスピントロニクス分野が形成してい る.この分野では, 不揮発性, 超高速化・超省エネルギー 化・超高集積化できるという特徵を持つ新機能デバイスが期 待される.

本稿では，代表的なナノスピンデバイス（MRAM，スピ ン FET 及び円偏光半導体レーザー）を紹介し，最後に，筆 者らの研究グループの室温強磁性半導体及びそのデバイスの 現状について紹介する。

\section{2. 代表的なナノスピンデバイス}

スピントロニクスでは，用いる材料は様々で，金属，半金 属, 磁性金属, 絶縁体, 非磁性半導体や磁性半導体などとい うものが挙げられる.これらの材料がへテロ構造, 混晶, 八 イブリッド構造やナノ構造によって, 混ざり合って使用され ている．例えば，既に商品化されている磁気へッド，ハード ディスクなどでは，金属と磁性金属（遷移金属化合物）材料 が用いられている．遷移金属化合物ベースのスピントロニク スは歴史が長く，応用範囲が広い。半導体スピントロニクス

*1 大阪大学産業科学研究所（干567-0047 大阪府茨木市美穂ヶ丘 8-1)
は潜在的に高いポテンシャルを持っているが, 現状として は，まだ多くの応用に繋がる研究が必要である.

半導体スピントロニクスは, 半導体マグネトエレクトロニ クスと半導体量子スピンエレクトロニクスに分けられる1). 前者は, 半導体と磁性体の融合した形で, 電子スピンデバイ スと光学スピンデバイスというものである. 後者は, 非磁性 半導体を使うもので, 長いコヒーレンス時間を持つスピンを 光と電場によって制御できる量子スピンデバイスである．こ こでは, 前者に属する代表的な, 重要なデバイスを紹介す る. 電子スピンデバイスとしての MRAM とスピン FET, 及び光学スピンデバイスとしての円偏光半導体レーザーを紹 介する。

\subsection{MRAM}

1975年に, 最初に Julliere ${ }^{2)}$ が強磁性トンネル接合による 強磁性トンネル磁気抵抗効果 (TMR; Tunnel Magnetoresistance）を報告した. $\mathrm{Fe} / \mathrm{Ge} / \mathrm{Co}$ 接合から, 強磁性体のス ピン依存伝導が確認された. その後, 1988年フランスの Baibich $^{3)}$ 及びドイツの Grenberg らによって, 巨大磁気抵抗 効果（GMR; Giant Magnetoresistance）が発見された。そ れを契機に, 磁気へッドの性能は飛躍的に向上し, 近年の HDD の記録密度は年 $100 \%$ もの驚異的な上昇を続け，乙か も, 安価になっている. 一方, TMR 効果を利用した夢のメ モリーMRAMの研究開発も精力的に行われている. 2003 年では, 米 Motorola は世界初の 4 Mbit MRAM をサンプル 出荷し, その翌年, $16 \mathrm{Mbit}$ という大容量を実現した. 現在, Gbit 級に向けて, 各種技術開発が行われている. 従来の DRAM，SRAM やFLASH など半導体メモリは電子の電荷 によって情報を保持している.これに対して, MRAM では 従来のメモリとはまったく違った原理で, 電子のスピンで情 報を保持するようになる. そのため, 不揮発, 大容量, 高 速, 低消費電力, 非破壊読久出し, 低電圧駆動, 無限回書き 換え可能という特徵を持っている. CPUとの集積により, 携帯情報機器などの小型化だけでなく, DRAMのようなリ フレッシュ動作が必要でないため, 低消費電力化・高速化も 実現できる。 


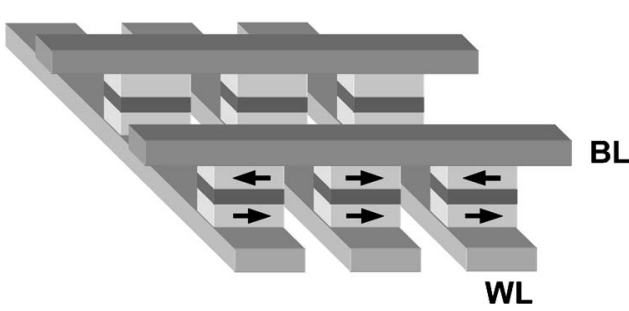

(a)
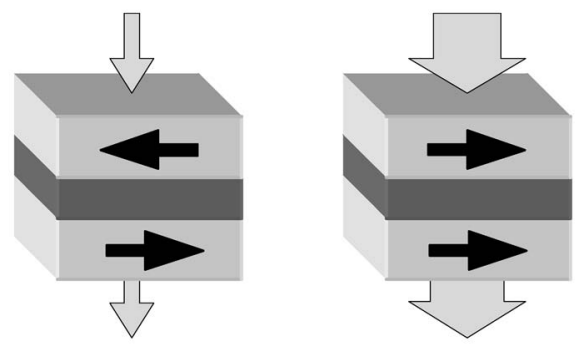

(b)

図 1 (a) MRAM 素子構成の概略図, (b) TMR 効果.

MRAM は TMR 素子を交点に，ビット線（BL）とワー ド線（WL）のマトリックス状に配線した構造となっている (図1(a)). 図1(b)のように, TMR 素子の基本構造は強磁 性層/非磁性層/強磁性層の三層構造からなる，TMR 素子で は一方の強磁性体層のスピン向きが固定され(図では下部),

もう一方では外部磁場によってスピン向きが変えられるよう になる (図では上部)。図のように，スピンが平行な場合 は, TMR 素子の電気抵抗が小さく, 反平行な場合, 電気抵 抗が大きい，二つの強磁性層のスピソの向きが平行な場合を 0 , 反平行な場合を 1 と定義すると, 電気抵抗の変化を検出 することで，TMR 素子に蓄積されているビット情報を読み 取ることができる，書き込みは，BLとWLにパルス電流を 流し，その合成磁界により図では上部の強磁性層のスピン向 きを反転させたりする。

これまで, 強磁性層は, 通常では, 遷移金属磁性元素 $(\mathrm{Fe}, \mathrm{Co}, \mathrm{Ni})$ ，または，それら合金 $(\mathrm{CoFe}, \mathrm{CoFeNi}$ や $\mathrm{NiFe}$ など）が用いられてきた．半導体を用いた TMR 素子の研究 は，東大の田中らにより最初に行われだ)。半導体の TMR は，多くの利点がある．半導体基板と整合性がよく，しか も，エピタキシャル成長により，原子層まで制御が可能で， 現有の製造機器を利用できるため，プロセスや集積化がかな り有利である。

図 2 は $\mathrm{Ga}_{1-\mathrm{x}} \mathrm{Mn}_{\mathrm{x}} \mathrm{As}(\mathrm{x}=4.0 \%, 50 \mathrm{~nm}) / \mathrm{AlAs}(1.6 \mathrm{~nm}) /$ $\mathrm{Ga}_{1-\mathrm{x}} \mathrm{Mn}_{\mathrm{x}} \mathrm{As}(\mathrm{x}=3.3 \%, 50 \mathrm{~nm})$ からなる単一障壁強磁性半導 体トンネル接合の $8 \mathrm{~K}$ に抢ける磁化特性とトンネル抵抗の 磁場依存性を示す，磁化特性にステップ構造が見られ，磁場 が 60 及び 100 Oe で二段となっている. 図 2 (b) は抵抗一磁場 と TMR 曲線を示す．実線は磁場を正加負へ，点線は負か ら正へ変化させたときを示している，二つの $\mathrm{Ga}_{1-\mathrm{x}} \mathrm{Mn}_{\mathrm{x}} \mathrm{As}$ 層 が平行の時, 電気抵抗は $0.015 \Omega \mathrm{cm}^{2}$ で，反平行の時， 0.025 $\Omega \mathrm{cm}^{2}$ である. TMR 比は $72 \% に も$ 達した。この構造では， GaMnAs 中のスピン偏極率は約 $50 \%$ あるあことがわかっ た. 強磁性半導体を用いた TMR 素子作製の成功は今後の半

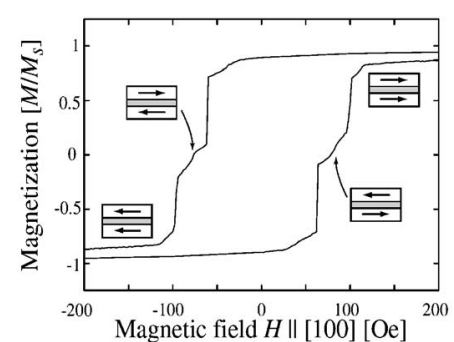

(a)

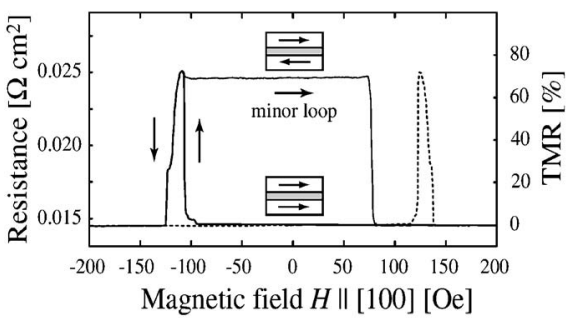

(b)

図 2 単一障壁強磁性トンネル接合の (a) 磁化曲線, (b) 磁気 抵抗と TMR 曲線4).

導体スピントロニクスに大きな推進力になると考えられる.

\section{2 スピン FET}

スピンと電荷を利用した MRAM は, DRAM などの半導 体メモリと比べて非常に利点の多い夢のデバイスとも言える. MRAMのように，現在は金属が主流であるが，しかし，論 理回路の場合, やはり半導体を用いることで, 能動デバイス を実現できる、スピンFETはトランジスタであり，構造的 には，従来のFETによく似ているが，しかし，主役は電荷 ではなく, スピンが主役である. 現在の半導体エレクトロニ クスは，サイズを小さくするにつれて，集積回路の動作速度 が向上し, 消費電力も小さくなる，その発展は，限界がくる ことが予測されている，そこで，電子の一つの性質であるス ピンが重要な役割を果たすようになると期待されている。 ス ピンFET は代表的な超高速, 省電力な機能デバイスであ る.

スピン FET は 1990年に, S. Datta と B. A. Das（当時は Purdure 大学)によって提案された ${ }^{5)}$. スピンFETではソー スとドレインが強磁性体になっている（図 3)。ゲート電圧 を加えていない場合では, ソースから電子がスピンの向きを 保ったまま半導体二次元電子ガスチャンネルを通過し, ドレ インへと移動する．ソースとドレインのスピンの向きが同じ であるため, 電流が流れやすい，一方，ゲート電圧を加える と, 電場が生じ, チャンネル内の電子スピンの向きがスピン 軌道相互作用によって回転し, ドレインに到達する時点で, ドレイン内のスピン向きと逆になる.TMR 構造と同じよう に, 電流が流机にくくなる. 従来型 FET ではゲート電圧を 加えると反転層ができて電子輸送が起こるが，スピン FET はこれと正反対の動作となる. 従来の FET と比べ, 反転層 を作るよりも，スピンを逆転させるのがより小さなエネル ギーで済むわけで，省電力になる．また，スピンFETには メモリ効果がある. ドレインの磁化方向は, 外磁場によって 変えることができる，そうすると，書き換え可能な不揮発性 


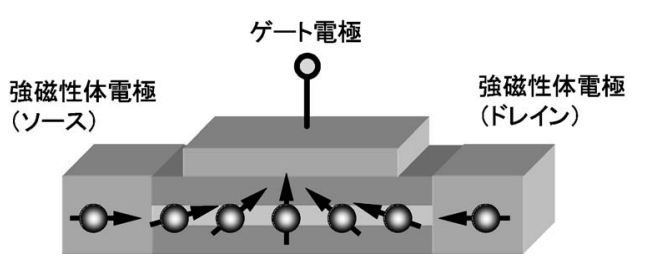

図 3 スピントランジスタの概念図.

電子回路が可能である。

現状では，スピンFETを実現するには，まず，解決すべ き二つ重要な問題がある. 一つ目は, 強磁性体電極から半導 体チャンネルへのスピン注入効率問題である. 注入効率を如 何にあげるかは，スピン FET だけでなく，スピントロニク ス全体に関わる問題でもある。二つ目は，スピン軌道相互作 用のゲート電圧による制御ができるかどうかである6 ${ }^{6}$.

半導体へのスピン注入の最初の報告は, 希薄磁性半導体 $\mathrm{GaMnAs}$ を用いた $\mathrm{GaAs} へ$ 注入に関するものである7,8).

GaMnAs は, キュリー温度が低いため, 室温でのスピン注 入が実現できない，ただ，希薄磁性半導体電極を用いる最大 の利点はその伝導率が注入される半導体層と同じであるた め，高い注入効率が期待される。一方，金属磁性体電極から のスピン注入の場合，スピン注入効率を上げるには，強磁性 体と半導体との間に，スピンフィルター機能を果たすトンネ ルバリアを設ける必要がある。近年, $\mathrm{MgO}$ トンネルバリア を介した大きな MR 変化率が示されている ${ }^{9,10)}$.

一方，スピン軌道相互作用のゲート電圧による制御に関し ては, 実験的に, シュブニコフ・ドバース振動のビートパ ターンを観察することによって，ゲート電压によるスピン軌 道相互作用の制御が可能であることが示されている11).

以上のような二つの問題を解決しつつあり, スピン FET の実現が近づいている.

\section{3 円偏光半導体レーザー}

円偏光半導体レーザーは光通信にとって非常に価値のある ものである.レーザー光の偏光に qubit の情報を乗せて伝送 する方法は, セキュリティ性が極めて高いと言われている. 円偏光半導体レーザーを実現するには，MRAM とスピン FET と同様に，高効率のスピン注入が不可欠である。ま た，第一歩として，円偏光を発するLED (Light Emitting Diode) の実現が必要である. 次のステップとして，共振器 面を持つレーザー構造とし, 電流注入によって発生した偏光 した光を共振させ，円偏光レーザー光を得ることができる.

世界で初めて希薄磁性半導体を用いて円偏光発光 LED を 実現したのは, Ohnoらの研究グループである. 図4(a)で は, 強磁性半導体 GaMnAs を用いた LED 構造を示す12). GaMnAs からのスピン偏極したホールを量子井戸層の InGaAs に注入し，電子と再結合することによって，円偏光を 発する. 発光ピークエネルギーは約 $1.35 \mathrm{eV}$ である. 図 4(b) では，スピン偏極率 $\mathrm{P}=\left(\sigma^{+}-\sigma^{-}\right) /\left(\sigma^{+}+\sigma^{-}\right)$の磁場及び温 度との関係を示しているもので, ゼロ磁場で $1 \%$ を達成し た．ここで， $\sigma^{+}$は右円偏光で， $\sigma^{-}$は左円偏光である.

一方, スピン注入は強磁性半導体ではなく, 非磁性半導体 のスピンホール効果を利用し, LED 構造への注入もできる.

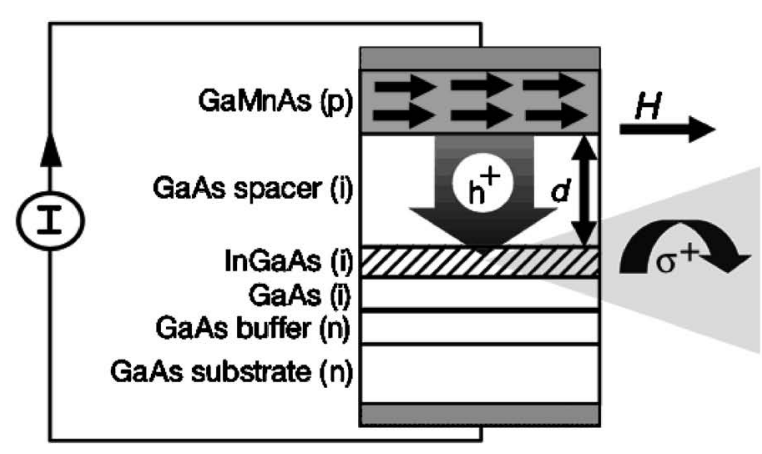

(a)

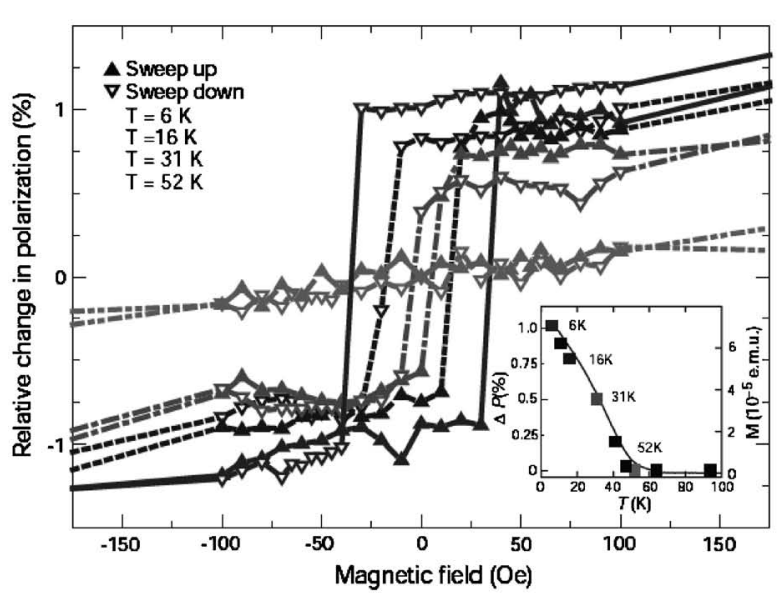

(b)

図 4 (a) 円偏光を発する LED 構造図，(b)スピン偏極率の磁 場依存性及び温度依存性 (挿入図 $)^{8)}$.

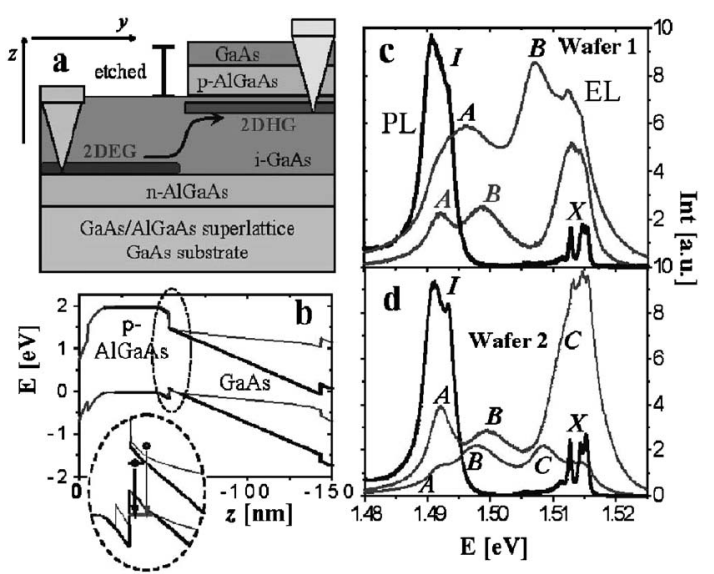

図 5 スピンホール効果を利用した (a) LED 構造，（b)バンド 構造 (c) (d) PL と EL スペクトル13).

2005年に日立ケンブリッジ研究所は, 図 5 (a)のようなラテ ラル構造のスピンLED を用いて, スピンホール効果を確認 した. スピンホール効果は，1971年に最初に予測され15,16), 2004年に California 大学 Santa Barbara 校でカー効果を利用 して初めて観察に成功した ${ }^{17)}$. スピンホール効果とは, 伝 導体に電流を流すと, スピン軌道相互作用により, 上向きス ピンと下向きスピンのホールが逆向きに曲げられて電流路の 


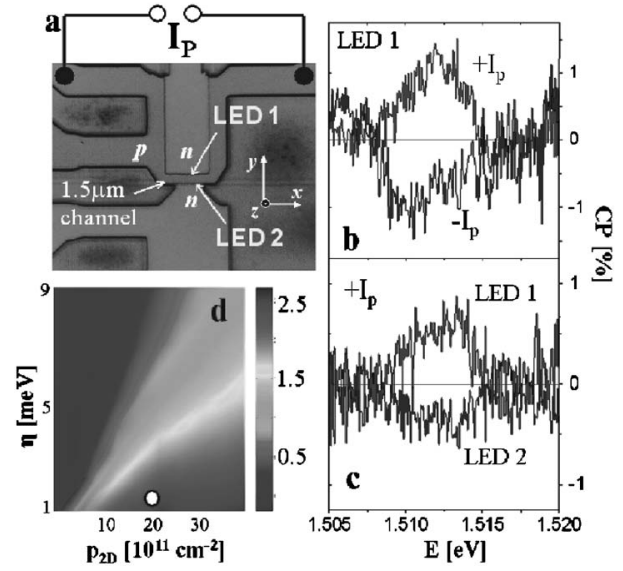

図 6 (a) スピンホール効果を利用した LED の SEM 像，(b) (c) 各エネルギーに抢ける LED1 及び LED2 からの発光 の偏極率，（d）Kubo 式によるスピンホール伝導率の計 算結果 ${ }^{13)}$.

両端に蓄積する現象である，図 5(a)のように，スピンホー ル効果により， 2 次元ホールガス（2DHG）を電流路の両側 に発生させ，それと隣り合わせて，2 次元電子ガス（2DEG） を作った（図 5(a)，(b)). その電流路の両端にそれぞれ一個 のLED 構造を設けた形になる（図 6(a))。試料に流す電流 の向きによって, LED1 からの光の偏光の符号が反転するこ とが確認できた（図6(b)). 更に, 流す電流向きが同じで,

二つの LED1 と 2 からの光の偏光が反対であることを観察 した (図6(c))。このようにスピンホール効果が確認でき た. スピンホール効果を利用することで， スピン注入効率が 格段に向上でき, 非磁性半導体を利用するのが特徵である.

2005年にスピン注入が面発光レーザー構造を用いて行わ れた ${ }^{14)}$. スピン偏極したホールを $\mathrm{InGaAs} / \mathrm{GaAs}$ の量子井戸 に注入に, EL 発光が観測された. EL 発光スペクトルを図 7 (a)に示す。スピン偏極率が $80 \mathrm{~K} て ゙$ 約 $4.6 \%$ を達成した（図 $7($ b) ).

強磁性体 (強磁性金属, 強磁性半導体) 及びスピンホール 効果を利用して, LEDへのスピン注入ができた. 将来的に は，スピンFETのように，高周波の電場を用いて，超高速 で電子（ホール）のスピン向きを変化させてレーザー構造に 注入し, そのスピン向きに応じて, 左或いは右円偏光レー ザー光が作られることも考えられる.

\section{GaN ベースの磁性半導体及びそれを用いた デバイス}

半導体スピントロニクスでは，様々な新機能デバイスが登 場し，次世代の情報通信に大きな夢を我々に与えてきたと同 時に，様々な課題も残されている. 一番大きな問題はやはり 材料のキュリー温度である. デバイスを室温で動作させるに はキュリー温度が室温を超える強磁性半導体が必要である.

室温強磁性半導体材料へのアプローチは, III-V 族, IIVI 族, IV 族などの様々な材料系で展開されている.ここで は, 筆者らのグループで研究されている遷移金属及び希土類 元素添加 $\mathrm{GaN}$ の特性及びそれらを用いたデバイスについて 紹介する.

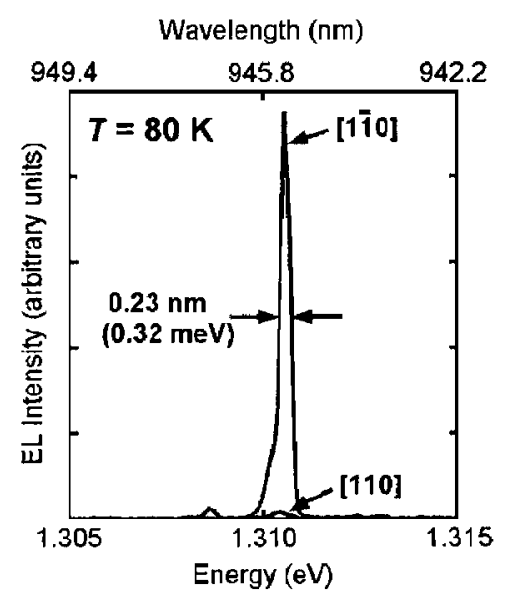

(a)

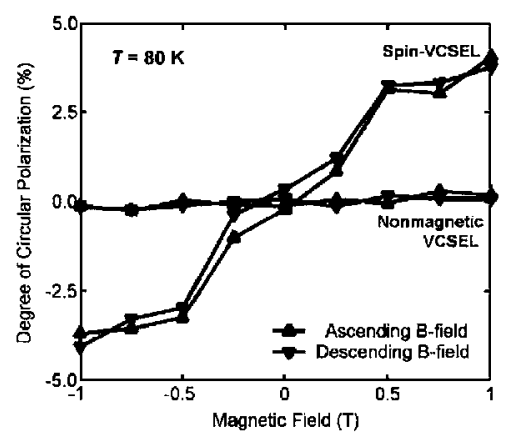

(b)

図 7 (a)スピン偏極面発光レーザーの EL スペクトル及び (b) 発光のスピン偏極率の磁場依存性 ${ }^{14)}$.

\section{1 遷移金属原子添加 $\mathrm{GaN}: \mathrm{GaCrN}$}

$\mathrm{GaCrN}$ は, III 族原料として固体 $\mathrm{Ga}, \mathrm{V}$ 族原料としてプ ラズマ励起の窒素 $\left(\mathrm{N}_{2}\right)$ ガス, 遷移金属として固体 $\mathrm{Cr}$ を用 いた MBE 法により成長させた。 サファイア基板表面を 800 ${ }^{\circ} \mathrm{C}$ で15分間熱的クリーニングを行った後, $\mathrm{GaN}$ 低温バッフ ア層を $400^{\circ} \mathrm{C}$ で約 $2 \mathrm{~nm}$ 堆積させ, 成長温度 $650-700^{\circ} \mathrm{C}$ ま゙基 板を昇温することで再結晶化させた後に, $\mathrm{GaN}$ バッファ層 を成長させ，その上に $\mathrm{GaCrN}$ の成長を行った. 成長された $\mathrm{GaCrN}$ は透明で表面は鏡面状態である. 約 $2 \%$ 以下の $\mathrm{Cr}$ 濃 度に対して相分離のない結晶が得られた。 C 濃度約 $1.5 \%$ の $\mathrm{GaCrN}$ の X 線回折パターンから, $\mathrm{GaCrN}$ 及びサファイア基 板の回折ピークのみが観測されている ${ }^{18)}$. 伝導型は $\mathrm{n}$ 型で あり, $10^{18} \mathrm{~cm}^{-3}$ 台半ばのキャリア濃度をもっている.

この試料に対する SQUID 測定による磁化一磁場 $(\mathrm{M}-\mathrm{H})$ 曲線を図 8 に示す ${ }^{18)} .7 \mathrm{~K}, 300 \mathrm{~K}$ 両温度において, 明瞭な 磁化ヒステリシス(挿入図) と磁化の飽和が観測されている. $\mathrm{GaCrN}$ は低温でも高温でも, 強磁性的に振舞うことが見出

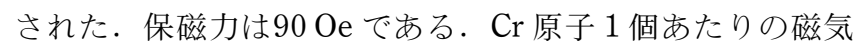
モーメントは $2.6 \mu_{\mathrm{B}}$ である. 磁化-温度 (M-T) 曲線をみる と, $\mathrm{GaCrN}$ のキュー温度は $400 \mathrm{~K}$ 以上であることが予測 できる18).

InAs, GaAs ベースの磁性半導体 InMnAs, GaMnAs は相 分離を抑制するために InAs, GaAs の通常成長温度に比べか 


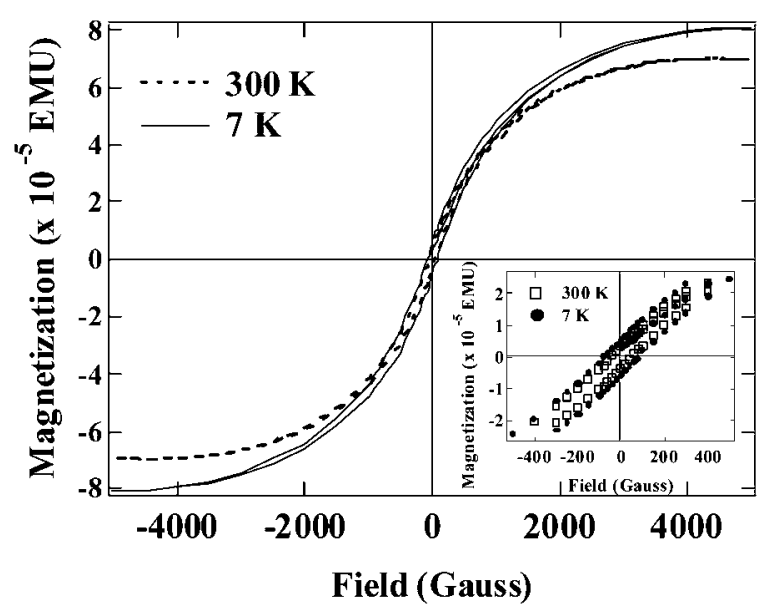

図 $8 \mathrm{GaCrN}$ サンプルの磁化の磁場依存性.

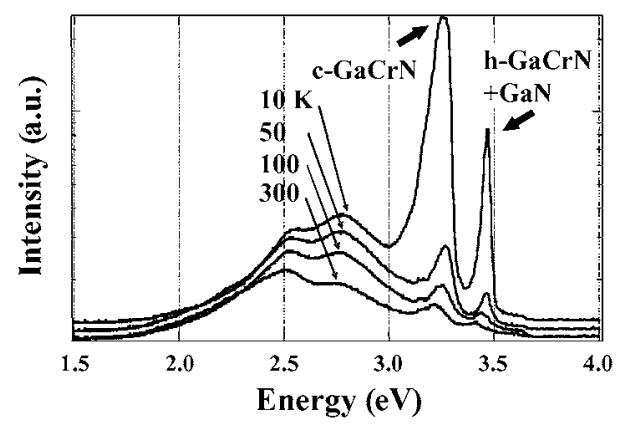

図 $9 \mathrm{GaCrN}$ サンプルからの PL 発光スペクトル.

なり低温で成長されており，発光が観測されていない。しか し, $\mathrm{GaN}$ ベースの磁性半導体は, ほぼ通常の $\mathrm{GaN}$ 成長温度 で成長を行うことができるため, 室温でも比較的強いフォト ルミネセンス (PL) 発光が観測された。図 9 は $\mathrm{GaCrN}$ の 10-300 K での PL 発光スペクトルを示す ${ }^{19)}$. 約 $3.2 \mathrm{eV}$ の ピークは立法晶 (cubic) の $\mathrm{GaCrN}$ によもので, 3.5付近 のピークは六方晶 (hex) の $\mathrm{GaCrN}$ と $\mathrm{GaN}$ にるものと判 断されている.

このように, $\mathrm{GaCrN}$ は発光し, 電気伝導を示し, また, 室温強磁性を示すことから, 応用上非常に重要な特性を持つ.

\section{2 希土類原子添加 GaN : GaGdN}

希土類原子添加の $\mathrm{GaN}$ は希土類原子の原子準位間の電子 遷移に基づく鋭い発光が得られることが知られている. 希土 類原子の種類により, 赤, 緑, 青 (RGB) の 3 原色の発光 が可能であり, 表示素子への応用が考えられている. また, 希土類原子は空間異方性の $\mathrm{f}$ 電子を持ち, 希土類添加の $\mathrm{GaN}$ でも強磁性を示すと期待される.

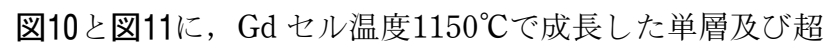
格子構造の磁化一磁場曲線を示す。これらの試料からは, 室 温での強磁性を確認した. $10 \mathrm{~K}$ 及び $300 \mathrm{~K}$ の磁化曲線を比 較すると, 単層膜よりも, 超格子構造の方が単位体積あたり の磁化が大きく, 温度変化が大きいことが見られる. 現在, この理由は不明であるが, 相分離という可能性を除けば, キ ヤリア(電子)が磁化を増大させた可能性がある.すなわち, $\mathrm{Gd}$ を GaN に添加すると, バンドギャップが少し縮み, 電

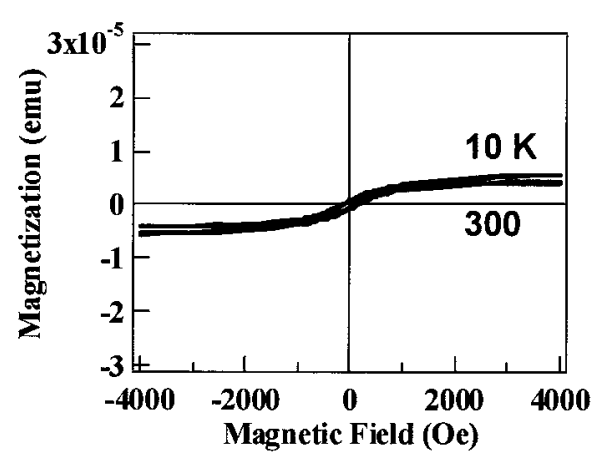

図10 $10 \mathrm{~K}$ 及び $300 \mathrm{~K}$ における単層 $\mathrm{GaGdN}$ 膜の磁化一磁場曲 線.

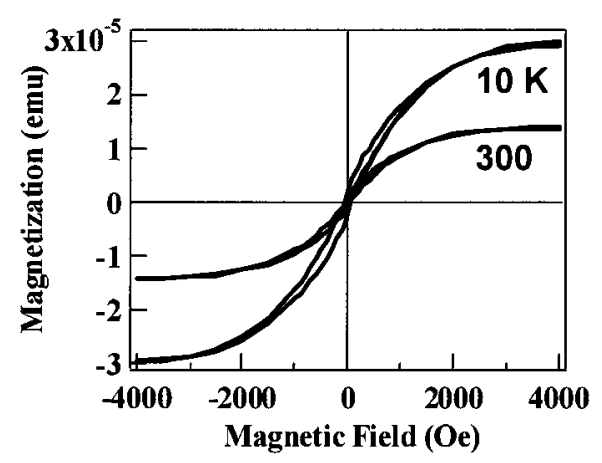

図11 $10 \mathrm{~K}$ 及び $300 \mathrm{~K}$ における超格子 $\mathrm{GaGdN} / \mathrm{GaN}$ の磁化一 磁場曲線.

子は $\mathrm{GaGdN}$ 膜に流れ込み, 超格子構造にすることによっ て, 単層膜より, 超格子中の GaGdN 膜により高いキャリア 濃度が存在すると予測できる. このために, より大きい磁化 が誘起されたと考えられる。

\subsection{GaCrN を用いた TMR 素子}

$\mathrm{RF}-\mathrm{MBE}$ 法を用い， $\mathrm{GaCrN} / \mathrm{AlN} / \mathrm{GaCrN}$ 三層構造を作製 した. 化学的, 熱的に清浄化された $\mathrm{n}-\mathrm{GaN}$ 基板上に $1 \mathrm{~nm}$ の高温の $\mathrm{GaN}$ バッファを成長させた後, $30 \mathrm{~nm}$ の第 1

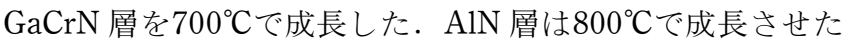
後, 第 $2 \mathrm{GaCrN}$ 層を $700^{\circ} \mathrm{C} て ゙ 250 \mathrm{~nm}$ 成長してから $\mathrm{GaN}$ キ ヤップ層を積んだ。第 1 と第 $2 \mathrm{GaCrN}$ 層の $\mathrm{Cr}$ 濃度はそれ ぞれ $1 \% ， 2 \%$ であ。

成長終了後, AFM を用いて表面観察を行った結果, RMS 值は $0.792 \mathrm{~nm}$ であり, 平坦な表面が得られたことを確 認した. 三層構造の界面を TEM で観察した. 図12に示した ように平坦な界面が形成していることが確認され, AlN 層 の厚さが $3 \mathrm{~nm}$ であることがわかった.

試料の磁化の磁場依存性は SQUID 磁束計を用いて行っ た. 試料のサイズは $4 \times 4 \mathrm{~mm}^{2}$ であり, 外部磁場は試料面に 平行に印加した. $10 \mathrm{~K}$ から $300 \mathrm{~K}$ まで測定を行い，すべて の温度においてヒステリシスが観測された. 磁化一磁場曲線 から, 飽和磁化に達する磁場は約 $4000 \mathrm{G}$ であり, 140 Oe の 保持力を持っていることを確認した.

スピン依存輸送特性を調べるため, 試料に対してトンネル ダイオードを試作した（図13）. まず，反応性イオンエッチ ングを用いて MESA 加工（ $\phi 300 \mu \mathrm{m}$ 径）した後, $\mathrm{Au}(150$ 


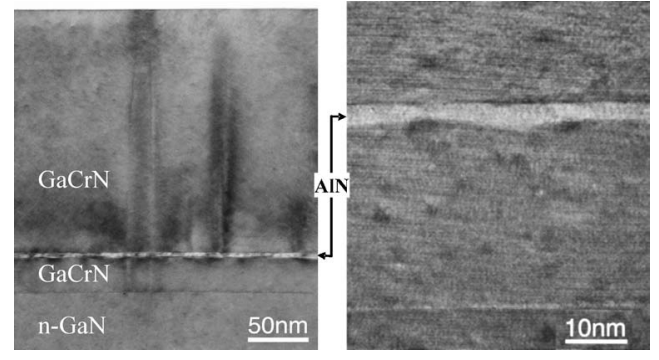

図12 $\mathrm{GaCrN} / \mathrm{AlN} / \mathrm{GaCrN}$ 三層構造の TEM 像.

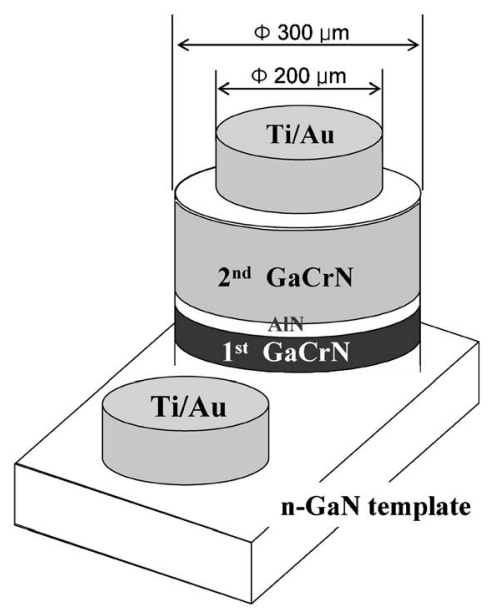

図13 $\mathrm{GaCrN} / \mathrm{AlN} / \mathrm{GaCrN}$ トンネルダイオード構造.

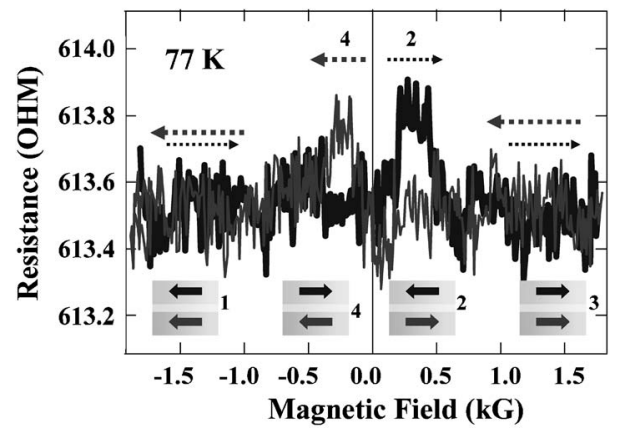

図14 $\mathrm{GaCrN} / \mathrm{AlN} / \mathrm{GaCrN}$ 三層構造の磁気抵抗の磁場依存性.

$\mathrm{nm}) / \mathrm{Ti}(12 \mathrm{~nm})$ を蒸着（ $\phi 200 \mu \mathrm{m}$ 径）してからオーミック 接触形成のために窒素䨌囲気中 $500^{\circ} \mathrm{C}$ で 1 分間アニーリング を行ったＩ-V 測定の結果， $\mathrm{AlN}$ 層がトンネル障壁として働 いていることが分かった. ダイオード試料に対して $77 \mathrm{~K} の$ 温度で磁気抵抗の磁場依存性を調べた。 $0.1 \mu \mathrm{A} の$ 電流は試 料面に垂直に流し, 磁場は面に平行に印加した. 図14が測定 結果である. 印加した外部磁場による $\mathrm{GaCrN}$ 層間のスピン 依存散乱の大きさに比例して磁気抵抗が変化するトンネル磁 気抵抗効果を観測した. 図で示しているように外部磁場を+ $2000 \mathrm{G}$ まで徐々に上げると, $2 つ \mathrm{GaCrN}$ 層のスピンは外部 磁場方向に揃い, その後逆に $-2000 \mathrm{G}$ まで徐々に変化する 々 $-200 \mathrm{G}$ 付近で $\mathrm{GaCrN}$ 層間のスピンの向きが反平行にな ってスピン依存散乱が大きくなって, 磁気抵抗が大きくなっ ている. 更に磁場を減少させると, 2 つ $\mathrm{GaCrN}$ 層のスピン
は外部磁場方向に揃って, 磁気抵抗が小さくなっている. た, この状態から, $+2000 \mathrm{G}$ までゆっくり増加させると, $300 \mathrm{G}$ 付近で $\mathrm{GaCrN}$ 層間のスピンの向きが反平行になって 磁気抵抗が大きくなっている.トンネル磁気抵抗比は Julliere モデルによって計算すると $0.1 \%$ ある.

\section{4. 結 論}

半導体スピントロニクスは次世代の情報通信に大きなポテ ンシャルを持っている. スピン依存伝導, スピン注入, スピ ン軌道相互作用, スピンホール効果などのスピントロニクス にとって重要な物理現象を如何に利用し, 制御するかは, 今 までにない多彩な新機能デバイスにつながる.

一方, $\mathrm{GaN}$ ベースの室温強磁性半導体においては, 室温 強磁性の発現メカニズムの解明は, 磁性半導体に扔ける強磁 性制御の基本問題となり, 理論的にも, 実験的にも双方のア プローチが不可欠である. それと同時に, $\mathrm{GaN}$ 磁性半導体 ベースのスピン注入デバイスなどのスピン現象関与したデバ イスを作製して, 更なるデバイスとして検証することが重要 である. 特に, ナノ構造（超格子, 量子細線, 量子ドット) にすることによって, $\mathrm{GaCrN}$ を始めとする室温強磁性半導 体の磁性を制御することができる．また，ナノ構造はデバイ スの基本構造にもなるため, 熱的に安定性が高い $\mathrm{GaN}$ ベー スの室温強磁性半導体は室温だけでなく, 高温でも動作する スピントロニクス材料としても期待される.

\section{〔文献〕}

1) H. Ohno, F. Matsukura and Y. Ohno: JSAP International No. 5, (2002) pp. 4-13.

2) M. Julliere: Phys. Lett., 54 A (1975) 225.

3) M. N. Baibich, J. M. Broto, A. Fert, F. Nguyen, Van Dau, F. Petroff, P. Etience, G. Creuzet, A. Friederich and J. Chazelas: Phys Rev lett., 61 (1988) 2472.

4) M. Tanaka and Y. Higo: Phys. Rev. Lett., 87 (2001) 026602.

5) S. Datta and B. Das: Appl. Phys. Lett., 56 (1990) 665.

6) J. Nitta: FED Review, vol. 1, No. 10, 14 March (2002).

7) R. Fiederling, M. Keim, G. Reuscher, W. Ossau, G. Schmidt, A. Waag and L. W. Molenkamp: Nature, 402 (1999) 787.

8) Y. Ohno, D. K. Young, B. Beschoten, F. Matsukura, H. Ohno and D. D. Awschalom: Nature, 402 (1999) 790.

9) S. Yuasa, et al.: Nature Materials., 3 (2004) 868.

10) S. S. P. Parkin, et al.: Nature Materials., 3 (2004) 862.

11) J. Nitta, T. Akazaki, H. Takayanagi and T. Enoki: Phys. Rev. Lett., 78 (1997) 1335.

12) Y. Ohno, D. K. Young, B. Beschoten, F. Matsukura, H. Ohno and D. D. Awschalom: Nature, vol. 402, pp. 790-792, 16 Dec., 1999.

13) J. Wunderlich, B. Kaestner, J. Sinova and T. Jungwirth: PRL, 94 (2005) 047204.

14) M. Holub, J. Shin, S. Chakrabarti and P. Bhattacharya: Appl. Phys. Lett., 87 (2005) 091108.

15) M. I. D'yakonov and V. I. Perel: JETP Lett., 13 (1971) 467.

16) M. I. D'yakonov and V. I. Perel: Phys. Lett., A 35 (1971) 459.

17) Y. K. Kato, R. C. Myers, A. C. Gossard and D. D. Awschalom: Science, 306 (2004) 1910.

18) M. Hashimoto, Y. K. Zhou, M. Kanamura and H. Asahi: Solid Sate Com., 122 (2002) 37.

19) M. Hashimoto, Y. K. Zhou, M. Kanamura, H. KatayamaYoshida and H. Asahi: J. Cryst. Growth, 251 (2003) 327.

20) N. Teraguchi, A. Suzuki, Y. Nanishi, Y.K. Zhou, M. Hashimoto and H. Asahi: Solid State Com., 122 (2002) 651. 